\title{
The Development Perspective of Finance and Microfinance Sector in China: How Far Is Microfinance Regulations?
}

\author{
M. Wakilur Rahman (Corresponding author) \\ PhD Candidate, College of Economics and Management, Northwest A\&F University \\ 3, Taicheng Road, Yangling, Shaanxi, China-712100 \\ Assistant Professor, Department of Rural Sociology, Bangladesh Agricultural University, Bangladesh \\ E-mail: wakil_bau@yahoo.com \\ Dr. Jianchao Luo \\ Professor, Director, College of Economics and Management \\ Institute of Rural Finance, Northwest A\&F University, 3, Taicheng Road, Yangling, Shaanxi, China \\ E-mail: jianchaoluo2000@yahoo.com
}

This paper is supported by "study on openness, efficiency and policy system of rural financial market in west China' National Natural Science Foundation of China (NSFC), Jan 2011-Dec 2013, No.71073126, Host and Sponsor: Jianchao Luo

\begin{abstract}
The paper reviews the development process of bank and microfinance sector in China and presents their regulatory status. The financial sector is largely bank-based and dominated by the four state commercial banks in China. However, government liberal policy and special attention to financing underdeveloped regions and SMEs have gradually improved the scenario. The development of non-state banks, non-bank financial institutions and MFIs has extended financial services to the areas where state banks were previously not so active. Consequently, government banks, micro-credit companies along with some national and international MFIs and donor agencies have started their business a greater extent although the market freedom is still questionable. The benefit of microfinance services lies on favorable government policy formulation and allowing MFIs reasonable freedom toward smooth development. Thus, it is suggested that government authorities should take necessary steps for resolving the existing barriers of the promising microfinance sector in China.
\end{abstract}

Keywords: Finance, Microfinance, Microfinance regulation

\section{Introduction}

Financial access to all social groups particularly to the poor has become an important tool for reducing poverty and inequality for many developing countries in the world. China made unprecedented success in her economic and social aspects since reform and opening up started in 1978. It has made significant success in poverty reduction and rural development (ADB, 2008). For instance, official poverty fell from 15 percent in 1984 to 2 percent in 2007. However, the development of the financial sector is at a slower pace compared to other sectors in China's economy. China's financial sector is underdeveloped and inefficient in respect to market domination by four State Commercial Banks (SCBs), higher bank deposit and banks lending have misallocated (Aziz, 2002). In contrast, a substantial amount progress has been made in the reforming process. The important progress that has occurred are the restoration of a commercial banking system, development of non bank financing, rural financing, special priority to Small and Medium Enterprise (SMEs), micro-lending and the introduction of NGO-MFIs.

Microfinance is the financial provision to the poor who are traditionally not served by the conventional financial institutions. These institutes not only provide credits but also provide supplementary services i.e deposit, insurance, remittance, education, health, market information, training, awareness building, forestation, and so on. Accordingly, several microfinance models have been developed in diverse political and economic contexts. The microfinance models have been trying to apply in China's financial market with reasonable modification (Sun, 2002). In reality, microfinance is a young but promising sector in China introduced in 1993 (MIFA, 2009). However, the potentiality of micro-credit is enormous in China in respect to large rural populations, unemployed workers, SMEs, micro enterprises, low rural coverage, limited outreach and high loan/deposit ratio of formal financial institutions (He, 2008). So, the donors, government authorities, and NGOs come forward targeting poverty reduction through micro lending in the less developed regions of China (Aghion, 2002). However, the commercialization did not really emerge in China until recently (He, 2009). Within 15 years of microfinance experience, China has drawn some specific techniques and models, introducing a system suitable to the Chinese situation. But, the provision of supplementary services has not popularized among China's microfinance clients and providers. Even, the market freedom and favorable policy regulation is still lagged behind.

Therefore, this paper's ultimate goal is to provide a consistent conceptual interpretation and discussion of the development process of the financial sector, and more specifically, the development of microfinance sector and the 
regulatory environment in China. However, the reviews have been limited to banking and microfinance sector rather to covering stock, bond and capital market in China.

\section{Financial sector development}

Finance is something which popular usage for covering medium to large scale funding either working capital or investment capital for enterprises or households to maintain its production process or businesses (Wijewardena, 2004). Discussion of the development of the financial sector covers two major parts, conventional banking system and microfinance sector. The development of conventional banking systems and microfinance sector both has been divided into three phases for further discussions-

\subsection{Development Phase-I (1978-83)}

Before 1978, China's financial system consisted of a single bank -the People's Bank of China (PBC), government owned and controlled by the Ministry of Finance, which served as a central and commercial bank. A significant change occurred in 1979 as government first removed the monopolistic position of PBC by establishing four specialized banks- the Agricultural Bank of China (ABC) has a mandate or rural financing, the People's Construction Bank of China (PCBC) has a mandate for investment and manufacturing financing, the Bank of China (BOC) for international financial transactions and finally the Industrial and Commercial Bank of China (ICBC) was formed in 1984, for working capital financing (Table-1). Finally, PBC has formally been established as China's central bank and a two-tier banking structure- PBC as central bank and state-owned specialized banks (SOBs) evolved. So, it is apparent that financial reforms have implemented in a gradual basis rather than revolutionary way like other sectors of the China's economy.

\subsection{Development phase II: $1984-1993$}

This period can be treated as broadening the financial market by allowing Non-bank Financial Institutes (NBFIs) beside "Big Four" banks. NBFIs, such as Trust and Investment Companies (TICs), finance companies, leasing companies, management companies, postal saving banks, insurance companies and securities companies have been allowed to emerge and compete with the state-owned banks (having restrictions on both deposits and loans). Regional banks (partially owned by local governments) were formed in the Special Economic Zones in the coastal areas. In rural areas a network of Rural Credit Cooperatives (RCCs) has been set up under the supervision of ABC. The Urban Credit Cooperatives (UCCs) counterparts of the RCCs in the urban areas have also been shaped (Dyar, 2006.).

\subsection{Development Phase III (1994 to date)}

The third phase can be treated as liberalization and international orientation of financial market in China. It is noted that microfinance or micro-lending activities were incepted in this phase. The section is discussed separately in the following part. In the reforming process, three policy banks were created in 1994 to disburse government-directed loans. It is legalized that the state-owned specialized banks can be converted to commercial banks (Shirai, 2002). New commercial bank law was enacted in 1995, giving the central bank legal foundation to operate in a market environment under the leadership of the State Council. Hence, a greater autonomy has been given for lending decisions and encouraged to create privately-owned commercial banks. In addition, a unified inter-bank market auctions for treasury bills and strict asset-liability ratios have been accomplished for commercial banks. The reforms have connected between banks and non-bank financial institutions and tightened regulations on stock exchanges (World Bank, 1997). Consequently, the government controls over financial institutions have been relaxed which is considered as a prominent aspect of financial sector reform. PBC influence on financial institutions has become more indirect and the credit ceiling of financial institutions no longer in existence. Beginning in 1998, lending quotas for state-owned commercial banks have lifted. Banks have been authorized to adjust interest rates within a 20 percent band depending on the borrower's creditworthiness. In the process of reform, foreign banks have allowed in special economic zones at first, and then gradually expand their (foreign exchange) business throughout the country. However, foreign banks have been subjected to national treatment concerning Renminbi business since 1995 (Hofman, 2009). Geographical and customer restrictions on RMB business for foreign banks have been removed gradually after China's accession to the WTO in 2001 (Table 1). Moreover, non-prudential restrictions on foreign banks' operations in China have also been removed. Accordingly, the achievements in China's economic and financial development have been well recognized by the international community. More and more foreign banks are establishing themselves in the vast and fast growing Chinese market, or seeking extensive and mutually beneficial business cooperation and partnership with their local counterparts (CBRC, 2007).

These reforms took place in the banking sector amid sustained economic growth and without macroeconomic disturbance. But, the performance of the Chinese financial system is still questionable due to unclear regulatory environment, lack of market freedom, business restrictions (different banking services) and so on. Whatever the limitations and constraints of banking system in China- China's financial sector has proved its efficiency, potentiality and set an example to the world during two big financial crises in 1997 and 2008.

\section{Microfinance development}

China has experienced fifteen years of microfinance services after successful inception in October 1993 as part of a government scheme for poverty alleviation. The development process of microfinance sector is discussed by following three phases- 


\subsection{Development Phase I (1994-1998)}

The phase can be regarded as an experimental phase; microfinance activities were limited with different development projects. Before 1994, some international foreign-aid projects in collaboration with other projects initiated credit plans for particular social groups (Table 2)- i.e. United Nations Women Development Fund (UNWDF) for creating employment opportunities of women, International Foundation for Agricultural Development (IFAD) for improving food supply and increasing the nutrition level of middle and low income households in rural areas, the "Women, Population and Development" project implemented by UNFPA for revolving capital, and Hong Kong Oxford for providing credit to rural households for livestock farming and veterinary services (Druschel, 2002).

The first experiment of microfinance on the successful Grameen Bank model was replicated by CASS in 1993 in China. The client was poor rural women in four project sites- Yixian County, Hebei; Nanzhao County, Henan; Yucheng County, Henan; and Danfeng County, Shaanxi. The initiation of this project is regarded as the real outset of microfinance activity in China (Saich, 2001). Hence, Funding the Poor Cooperatives (FPC) followed the Grameen Bank (GB) model, offering $8 \%$ interest rate (yearly), $5 \%$ of the loan is taken at the time of disbursement to serve as savings fund and 2 yuan (US\$0.25) is also saved from weekly repayment (Du, 2001). Loan is disbursed for one-year terms, weekly repayments are made, monthly or bi-weekly center meetings are conducted, and a first loan size is 1000 yuan (about US\$ 121). The loan size increases to 1500 yuan in the second year and 2000 yuan in the third year and it is capped at 2000 yuan.

\subsubsection{Brief introduction of Donor funded Microfinance program}

In 1995, UNDP undertook a microfinance experiment project at Yilong County, Sichuan Province. The project has expanded to 48 counties of 17 provinces and became one of the largest microfinance projects assisted by an international organization in China. In 2008, UNDP has taken another collaborative project with CETICE for building an inclusive Chinese financial sector. The project is intended to build a draft national strategy for financial inclusiveness and will be submitted to the State Council at the end of 2011 (UNDP, 2008). In 1996, the United Nations Children's Fund (UNICEF) began microfinance activities as social development program for poor areas. Beside micro-lending activities, UNICEF provided training on maternal and child health care. The United Nations Population Fund (UNFPA) began microfinance activities in 1998. Accordingly, several international and national organizations have come forward to micro-lending in China among others- World Vision (WV) began microfinance services in 1997, The Canada-China Women's Income Generating Project (CC97) began in 1997, Oxfam Hong Kong in Yunnan province since 1992, the China Foundation for Poverty Alleviation (CFPA) a Chinese non-governmental organization was formed in 1997 and Rural Credit Foundations (RCFs).

Parallel with the above microfinance projects, the government has also been providing loans in rural areas through three leading financial institutions since the 1990s- the Agricultural Bank of China (ABC), for larger farming units such as seed companies and marketing co-operatives; the Agricultural Development Bank of China (ADBC), for storing crops, distributing, marketing, or processing agricultural products, or for large-scale agricultural development projects; while the Rural Credit Cooperatives (RCCs) for township and village enterprises (TVEs), and to middle-income male farmers ( $\mathrm{Du}$ 2002; Zhu, et al. 1997). Hence, RCC is the first government bank providing micro loan to the farmers. RCCs have reached almost every township of rural China under the supervision of PBC. In 1996, the RCCs officially became independent entities (Watson 2002).

\subsection{Development Phase II (1999-2004)}

This phase has been labeled as the entire participation of formal financial institutions and the institutionalization of various projects. RCCs introduced micro-credit and group loan businesses for rural households in 1999. The experiment of RCCs have made success in some provinces like Shaanxi, Sichuan, Yunnan, Hebei, Guangxi, and Guizhou as they experienced faster microfinance growth (He, 2009). In the reforming process, the PBC has widely promoted micro-credit for rural households across the country. Thus, China has adopted micro-credit program from poverty alleviation project to rural financial sector. At present, RCCs is the largest microfinance practitioner in China as formal financial institutions.

Afterwards, in order to support the laid-off unemployed people for re-employed and meet the capital demand of that population, central government authorities (i.e. PBC, the Ministry of Finance (MOF), the State Economic and Trade Commission, and the Ministry of Labor and Social Security) encouraged local and provincial government to establish re-employment guarantee foundation since 2002. Consequently, laid-off unemployed are allowed start-up funds and working capital so as to uphold self-employment (Tang, 2009). This can be considered a holistic approach which satisfied laid-off unemployed through re-employment. The initiatives not only fulfilled the required funds but also expanded microfinance market from rural to urban areas in China.

\subsection{Development Phase III (2005- to date)}

The third phase can be treated as the normalization and institutionalization phase of microfinance. The phase begins with issuing a series of regulations by regulatory bodies in favor of microfinance development. In 2005, as China had experienced ten years of microfinance development, the PBC launched micro-loan companies (along with RCCs) in Sichuan, Guizhou, Shanxi, Shaanxi and Inner Mongolia provinces, pushing forward to popularization of 
microfinance in China (Tang, 2009). Hence, legalization of micro-loan companies was a significant event in the course of microfinance development in China as well as rural financial reform.

In the course of microfinance development, China Association of Microfinance (CAM) was set up in 2005. CAM consists of domestic MFIs, relevant administrative departments, and domestic and international organizations as well as experts and scholars which care for and support the undertaking of microfinance. It is a collaborative, service-oriented, and self-disciplinary organization. The five main functions of the CAM include: policy coordination, self-regulation, technical assistance and training, information exchanges, and fundraising services (CAM 2010).

In the process of liberalization, China Banking Regulatory Commission (CBRC) permitted postal saving banks to gradually develop collateral-based micro-loan services since 2006. At the same time domestic commercial banks and rural cooperative banks have also been encouraged to set up fully-owned lending companies specializing in credit business (similar to the micro-loan companies promoted by the PBC). These are Village and Township Banks (VTBs), Lending Companies (LC) and Rural Mutual Credit Cooperatives (RMCCs). The business scopes of VTBs and RMCCs focus on towns and counties as well as villages and towns respectively (He, 2009). Hence, the establishment of lending companies approved by the CBRC indicates another progress in the normalization course of microfinance in China. Additionally, since 2007, the CBRC encouraged micro-loan companies and all banking financial institutions to offer micro-credit to traditional farming households, households in a variety of businesses, sole proprietors and rural micro and small enterprises (Table-2).

Furthermore, CBRC allowed individual, corporate legal entities and other social organizations investment towards the establishment of micro-loan (not allowed to collect public deposits) companies in 2008. At present, micro-loan companies are allowed to raise their funds from shareholders' capital, donated funds, and borrow from not more than two banking financial institutions (CBRC, 2009).

\section{Microfinance structure and their services}

Since the first microfinance seed was planted in China, a vast number of different types of microfinance operators have appeared within the Chinese market. The structure of microfinance system in China is shown in Figure 1. Generally, there are three broad categories of microfinance service providers. These include-

\subsection{Micro-credit by financial institutes}

This category mostly includes state own formal microfinance service providers i.e. ABC, ADBC, RCCs, Rural Commercial Bank, Rural Cooperative Bank, Postal Savings, China Development Bank (CDB), MCC, VTB, LC, and RMCCs. The microfinance market share is dominated by these providers.

\subsection{Micro-credit by $N G O s$ \& international organizations}

The service providers are- NGOs, international organizations and social organizations. The international organizations have been providing financial services as project based with the collaboration of government agencies. They also incorporate different services beside micro-credit i.e savings, training in project sites. NGO lending services have covered countrywide and large volume of business.

\subsection{Micro-credit by Government agencies}

This category provides micro-credit focusing on the government poverty reduction program. For instance, Urban Credit Bank (UCB) was established to support laid-off workers which ultimately expanded micro-credit services to urban areas.

The comparative features of different microfinance service providers are shown in Table 3. Among microfinance suppliers, only NGO-MFIs and MCCs are non-financial institutions and consequently not allowed to work with savings or receive funding from commercial banks -thus, preventing them from enjoying economies of scale (CAM, 2008). Even the lending companies are also not allowed to work with savings. In addition, the three newly created rural financial institutions (VTBs, LCs, and RMCCs) as well as MCCs are subjected to geographical restriction. The traditional collateral system for micro-financing still exists particularly for micro-lending companies, lending companies, postal saving banks, MCCs, and VTBs. Even RCCs and UCCs have followed a special kind of collateral to credit disbursement. RCCs required collateral for large loan amounts and UCCs required companies guarantee. On the other hand, the donor funded projects (UNDP, UNFPA, UNICEF, Heifer Project, World Vision, Oxfam Hong Kong and CIDA) are allowed to providing micro-credit services by collaboration with government departments or agencies having certain conditions.

\section{Microfinance regulation}

Microfinance development phase III, mostly covered the regulatory framework of China's microfinance. However, this section has tried to deal with some key issues of regulations. China Banking Regulatory Commission (CBRC) is the prime authorized institute to handle and maintain the rules and regulations of banking and MFIs sectors. Thus, CAM imitative to build a regulatory framework for the microfinance sector has been suspended due to the lack of authorization from government (Sun, 2008). In fact, CAM was trying to construct microfinance regulations with the technical assistance from citi-training center of China Academy of Social Sciences (CASS). Up to now, there is still a lack of complete regulation for the microfinance sector in China. Accordingly, slow and low quality development 
of these NGO-MFIs has mainly been attributed to the limitations caused by an incomplete regulatory and supervisory system $(\mathrm{Du}, 2005)$. However, CBRC relaxation of interest rates and strong encouragement to micro-loan companies and village banks resulted in micro-lending coverage of 77 million household by the end of February 2008. With the approval of CBRC, commercial banks, NGOs and MFIs have started micro-lending services. At present, 91 village banks, 9 farmers' funding, 9 microcredit companies ( 7 domestic and 2 foreign) along with City Commercial Bank, ACLEDA, XAC Bank, and Grameen Bank have been providing financial services in China. According to CBRC report at the end of March 2009, 583 micro-finance companies have commenced their businesses in China which can be regarded as landmark for China's microfinance sector. CBRC has softened the requirements on SMEs loan applications procedures. Recently, government has planned to subsidize banks for the higher risk of lending to SMEs (World Bank, 2009, CBRC, 2009). So, emphasizing SMEs loan disbursement and government subsidization can be regarded as forward looking to expand the financial market in China. The most influential and favorable regulation for microfinance industries are-

\subsection{Creating business opportunity to National and International NGO-MFIs}

Gradually, opening up the market for financial intermediaries, i.e national and international companies, individuals, state own commercial banks, micro-loan companies, lending companies, VTBs, RMCCs, postal savings resulted in the continual development of the microfinance sector in China.

\subsection{Interest rate guidelines}

It is emphasized that the establishment of micro-loan companies does not mean loan-sharking and laissez-faire prices. The CBRC stressed that lending rates should not exceed the ceiling set by the central bank but the lower limit should be 0.9 times the benchmark rates. The floating ranges can be determined in accordance with market principles.

\subsection{Guideline for loan services}

Loan area: there are guidelines to distribute loans for all kind of agricultural services (production, processing, transportation, and circulation), all consumer areas (purchase of daily consumer products, high-end consumer durables, building or buying houses), medical treatment, children's tuitions, entrepreneurship, migrant workers, start-up businesses and vocational and technical training. Loan size: the guideline stipulates that the micro-credit loan size in developed regions and less developed regions can be increased to 100,000-300,000 RMB (\$1470-\$4412) and 10,000-50,000 RMB (\$1470-\$7353), respectively. Loan size can be decided on individual cases but within the above range for other regions. The group loan size can be increased to a moderate extent based on credit loan size, and the success rate of previous loan. Loan procedure: micro-credit providers are encouraged to simplify micro-loan procedures in rural areas including: applications procedures, loan processing time; using credit line cards, revolving lending within credit lines, and to improve the convenience level of borrowing.

Nevertheless, regulatory frameworks and policies governing microfinance in China remain vague and do not have a comprehensive framework. According to Prof. Muhammad Yunus, founder of Grameen Bank "...there should be a separate regulatory authority for MFIs as distinguished in character from that for the commercial banks. The regulatory authority for MFIs should evolve guidelines keeping in view the objectives of socio-economic development of the poor..", which is absent in China in the present context. UNDP China has also identified three interrelated deficits which hindering the development of micro-credit and other microfinance services in China. Among three difficulties the legal and regulatory arrangements is the first and foremost (UNDP, 2005).

\section{Conclusion}

From the above discussion, it appears that the banking and microfinance services have expanded and improved gradually. Hence, the banking sector is close to the maturity stage while the microfinance sector is still at learning stage. The government reforming initiative is quite good but still at an experimental level particularly for the microfinance sector. CBRC has been providing some favorable policy guidelines for the development of the banking and microfinance sectors within a controlled environment. For instance, creation of the four state owned banks from a mono bank system, introduction of private and commercial banks, creation of competitive environment, gradually opening the market for foreign banks from the special economic zones to all over the country, inter banks transactions, special attention to SMEs loan was the landmark achievement in the banking sector of China. In addition, market access of micro-credit service providers such as RCCs, RMCCs ADBC, micro-loan companies, VTBs, postal saving banks, NGO-MFIs have significantly contributed to mobilizing capital in rural areas. Even the introduction of UCC has created financial opportunities for the urban poor and laid-off workers. Last but not least, microfinance has enhanced the financial access to the poor who were excluded from the formal banking system in China like other countries in the world. In contrast, the collateral system of financing is still practiced by service providers including, micro-lending companies, lending companies, postal saving banks, MCCs, and VTBs. In addition, the business restrictions (NGO-MFIs, MCCs, Lending Companies are restricted to collect deposit) are still an obstacle for the smooth development of microfinance sector in China.

CBRC is the sole institute to deal with policy regulations for banks and microfinance service providers which may contradict to handle different goal oriented institutes (Banks and MFIs run their business in different perspectives). Therefore, it is recommended to the concerned authorities to have a balanced policy regulation for the microfinance 
sector to enhance its sustainability. Furthermore, building a separate regulatory authority should be prioritized. The enormous prospect of the microfinance sector should not be bottlenecked only for the sake of a sound regulatory environment.

\section{References}

ADB. (2008). Key indicators 2008: For Asia-Pacific, Comparing poverty across countries: the role of purchasing power parities, Asian Development Bank, Philippines

Aghion B. A. \& Sarah T. (2002). A Case for Successful Microfinance Programs in China Paper prepared for the $5^{\text {th }}$ Conference on Global Economic Analysis, Taipei, Taiwan, an for the Journal of Economics of Transition

Aziz, J \& Christoph D. (2002). Growth-financial intermediation nexsus in China, IMF working paper, Asia and Pacific Department, WP/02/194.

CAM. (2008). A glimpse at the microfinance industry in China, Promoting inclusive financial markets Workshop Report, World microfinance forum Geneva.

CAM. (2010). China Association of Microfinance, [Online] http://www.chinamfi.net/en/intro_aboutnet.asp.

CBRC. (2007). Report on the opening-up of the Chinese banking sector, China Banking Regulatory Commission, January 25, 2007.

CBRC. (2009). The CBRC issued the Provisional Rules Governing the Transformation from Micro-finance Companies to Village Banks, Guidance on the Pilot Program for Micro-finance Companies China Banking Regulatory Commission (CBRC).

Druschel, K. (2002). Microfinance in China: Building sustainable institutions and strong industries, Submitted for Master's of Arts to the School of International Service of American University, International Development.

Du, Xiaoshan. (2002). "Nongcun Jinrong Zuzhi Tixi Jianshe He Xiao'e Xindai [Microfinance and the Building of a Rural Financial System]" Jinrong Shibao [FinancialTimes].

Du, Xiaoshan. (2001). "China's Microfinance Practice and Policies." Microfinance to the Poor No. 2. Poverty Research Center, Chinese Academy of Social Sciences, Beijing.

Du, XiaoShan. (2005). The regulatory environment of Microfinance in China, Essay on regulation and supervision,

Dyar, C., Patrice, H., Cynthia K. \& Gabriela, R. (2006). Microfinance and gender inequality in China, prepared for the international economic development program, ford school of the public policy, University of Michigan.

He, Guangwen. (2008). An Analysis of Microfinance Demand in China, World, Microfinance Forum, Geneva, Promoting inclusinve financial market.

He G., Du X., B. C. \& Li Z. (2009). China Microfinance Industry Assessment Report, China Association of Microfinance.

Hofman, B. \& J. Wu (2009). Explaining China's Development and Reforms, commission on growth and development, World Bank, Washington DC. [Online] http://www.microfinancegateway.org/gm/document-1.9.27569/25978_file_China.pdf.

Laurenceson, J. \& J. C. H. C. (2003). Financial reform and economic development in China, Advances in Chinese Economic Studies series, Edward Egler Publishing limited, UK.

Mehran, H. \& Marc, Q. (1996). Financial Reforms in China, Finance and Development, International Monitory fund (IMF), Washington D.C.

Meyer, R, L. \& Geetha N. (2000). Rural financial markets in Asia: Policies Paradigms, and Performance, Study of Rural Asia: Vol. 3, Asian Development Bank.

MIFA. (2009). China Microfinance and financial sector diagnostic study, Final report, 2008. MIFA- promoting microfinance in Asia, IFC, Washington Dc, USA.

Saich, T \& Kaufman, J. (2001). Financial reform, poverty and the impact on Reproductive health provision: Evidence from three rural townships, paper presented at the conference on financial reform in China, Kennedy School of Government, September, 2001.

Shirai, S. (2002). Banking sector reform in the People's Republic of China- Progress and constraints" Chapter III, in Rejuvenation Bank finance for development in Asia and the pacific, United Nations.

Sun, T. (2008). The Policy and Legal Framework for Microfinance in China, World microfinance Forum, Geneva, Promoting inclusive financial market.

Sun, R. (2002). The Development of Microfinance in China (Final Draft), Rural Development Institute, Chinese Academy of Social Sciences.

Tang, L. (2009). Study on China's sustainable development of rural microcredit, International journal of business and management $\mathrm{Vol} 4$ (8):128-31. 
UNDP. (2005). Fast Facts, UNDP Support to Microfinance in China July-2005, United Nations Development Programme, China.

UNDP. (2008). Building an inclusive Chinese financial sector, Project summary, United Nations Development programme, China.

Watson, A. (2002). "Financing Farmers: The Reform of the Rural Credit Cooperative in China."

Wijewardena, W. A. (2004). Microfinance policy and regulatory framework: Experience and perspectives of south asian region - Sri Lanka, Bangladesh, Nepal and India

World Bank. (2009). World Bank Quarterly update November, 2009, World Bank Beijing [Online] http://siteresources.worldbank.org/INTCHINA/Resources/318862-1237238982080/5923417-1257229995645/cqu_ Oct_2009.pdf.

World Bank. (2007). Finance for All? Polices and Pitfalls in Expanding Access, Policy research report, World Bank World Bank. (1997). Financing Health Care: Issues and Options for China (Washington, D.C., The World Bank).

Zhu L., Jiang Z. \& Joachim von B. (1997). Credit Systems for the Rural Poor in China. Nova Science Publishers, Commack, NY. 
Table 1. Chronological development of banking sector in China

\begin{tabular}{|c|c|}
\hline \multicolumn{2}{|c|}{ Pre-reform period, prior to 1979} \\
\hline $\begin{array}{l}\text { Until } \\
1979\end{array}$ & - Monobank system. The People's Bank (PBC) functioned as central and commercial bank \\
\hline \multicolumn{2}{|c|}{ Phase I: 1979-1983 } \\
\hline 1979 & $\begin{array}{l}\text { - } \text { Established four State-owned specialized banks- } \\
\text { - } \mathrm{ABC} \text { for rural financing } \\
\text { - } \mathrm{PCBC} \text { for investment financing } \\
\text { - } \mathrm{BOA} \text { for international financial transactions } \\
\text { - } \quad \mathrm{ICBC} \text { for working capital financing ( established in 1984) }\end{array}$ \\
\hline 1981 & - The first treasury bonds were issued and sold on a compulsory basis \\
\hline 1983 & $\begin{array}{l}\text { - Two-tier banking system created } \\
\text { - Central bank created out of the PBC } \\
\text { - Competition allowed among the state owned specialized banks }\end{array}$ \\
\hline \multicolumn{2}{|c|}{ Phase II: 1984-1993 } \\
\hline 1984 & $\begin{array}{l}\text { - Control over RCCs shifted from } \mathrm{PBC} \text { to } \mathrm{ABC} \\
\text { - } \mathrm{RCCs} \text { begin servicing TVEs and households independently } \\
\text { - } \quad \text { The selected new banks were permitted to operate alongside these four banks }\end{array}$ \\
\hline 1985 & $\begin{array}{l}\text { - Financing responsibilities shifted from government to banks } \\
\text { - Foreign banks were permitted to set up branches }\end{array}$ \\
\hline 1986 & $\begin{array}{l}\text { - Provisional bankruptcy law passed for SOEs } \\
\text { - Local interbank centers have emerged }\end{array}$ \\
\hline 1987 & $\begin{array}{l}\text { - Nonbank financial institutions were allowed for business } \\
\text { - Competition among all banks and nonbank financial institutions were allowed }\end{array}$ \\
\hline 1991 & $\begin{array}{l}\text { - Separated commercial and policy-based lending } \\
\text { - } \text { market interest rates were allowed } \\
\text { - Encouraged banks to do better loan assessment and portfolio management }\end{array}$ \\
\hline \multicolumn{2}{|c|}{ Phase III: 1993 to date } \\
\hline 1993 & $\begin{array}{l}\text { - } \text { Refinance facilities from } \mathrm{PBC} \text { restricted } \\
\text { - State-owned specialized banks converted into real commercial banks } \\
\text { - } \text { Diversified financial market established } \\
\text { - } \text { Restrictions on lending to non-priority sectors were eased } \\
\text { - Comprehensive reforms introduced }\end{array}$ \\
\hline 1994 & - Three policy banks established to provide policy loans \\
\hline 1995 & - New commercial bank law was enacted \\
\hline 1996 & - Established an interministerial coordination group for rural financial system reform \\
\hline 1998 & $\begin{array}{l}\text { - All specialized banks allowed financing all sectors in rural areas } \\
\text { - Allowed foreign banks access to domestic inter-bank offering market }\end{array}$ \\
\hline 1999 & - Relaxing the geographical and volume restrictions of RMB business for foreign banks \\
\hline 2001 & $\begin{array}{l}\text { - China's accession to WTO } \\
\text { - Foreign banks were allowed to undertake foreign currency business }\end{array}$ \\
\hline 2003 & - Foreign banks were permitted to undertake corporate RMB business \\
\hline 2004 & - $\mathrm{RMB}$ business was opened to foreign banks in five cities \\
\hline 2005 & - $\mathrm{RMB}$ business was opened to foreign banks in seven cities \\
\hline 2006 & $\begin{array}{l}\text { - Geographical and customer restrictions of RMB business on foreign banks were removed } \\
\text { - The non-prudential restrictions on foreign banks' operations in China were removed }\end{array}$ \\
\hline
\end{tabular}

Sources: Compilation based on CBRC,(2007), Mehran(1996), Hofman, (2009) Shirai (2002),Meyer(2000), Laurenceson,(2003). 
Table 2. Chronological development of Microfinance sector in China

\begin{tabular}{|c|c|}
\hline \multicolumn{2}{|c|}{ Before 1994} \\
\hline $\begin{array}{l}\text { Before } \\
1994\end{array}$ & $\begin{array}{l}\text { - International foreign-aid projects with government collaboration- } \\
\text { - UNWDF for creating employment opportunities of women } \\
\text { - IFAD for improving food supply and increasing the nutrition level of middle and low income rural households } \\
\text { - UNFPA for revolving capital, and } \\
\text { - Hong Kong Oxford for livestock farming and veterinary services }\end{array}$ \\
\hline \multicolumn{2}{|c|}{ Phase I: 1994-1999 } \\
\hline 1994 & - $\quad$ the first experiment of Grameen Bank model was implemented in China \\
\hline 1995 & - UNDP undertook a microfinance experiment project \\
\hline 1996 & $\begin{array}{l}\text { - UNICEF started microfinance activities } \\
\text { - } \quad \text { RCCs officially became independent entities }\end{array}$ \\
\hline 1997 & $\begin{array}{l}\text { - World Vision (WV) began offering microfinance services } \\
\text { - } \quad \text { Established Rural Credit Foundations (RCFs) } \\
\text { - CIDA, Canada-China Women's Income Generating Project }\end{array}$ \\
\hline 1998 & - UNFPA began microfinance activities \\
\hline \multicolumn{2}{|c|}{ Phase II: 1999-2004 } \\
\hline 1999 & - RCCs introduced microcredit loan and group loan businesses \\
\hline 2001 & - $\mathrm{PBC}$ promulgated the Guidance on Microcredit Loans Management of RCCs \\
\hline 2002 & $\begin{array}{l}\text { - } \mathrm{PBC} \text { widely promoted microcredit loans for rural households across the country } \\
\text { - Established reemployment guarantee foundation }\end{array}$ \\
\hline 2003 & - Tax-credit rating management methodologies" issued by State Administration of Taxation \\
\hline 2004 & - Improvement in Granting Microfinance Loans and Serving the Rural Poor' \\
\hline \multicolumn{2}{|c|}{ Phase III: 2005 onward } \\
\hline 2005 & $\begin{array}{l}\text { - PBC launched pilot credit-only for microloan companies } \\
\text { - Established China Association of Microfinance (CAM) }\end{array}$ \\
\hline 2006 & $\begin{array}{l}\text { - Pilot Management to Strengthen Postal Savings Bank management } \\
\text { - Eased Market Access for Banking Financial Institutions }\end{array}$ \\
\hline 2007 & - CBRC promulgated the Guideline on How to Greatly Develop Rural Microloan Business \\
\hline 2008 & - allowed individual, corporate legal entities and other social organizations investment \\
\hline
\end{tabular}

Source: Complication of He, (2009), MFIT (2008), CAM, (2008), Tang (2009), Sun, (2008), Druschel, (2002) 
Table 3. A comparative features of micro-credit service providers

\begin{tabular}{|c|c|c|c|c|c|c|c|}
\hline $\begin{array}{l}\text { Type of } \\
\text { institutions }\end{array}$ & inception & Coverage & Beneficiaries & Collateral & Interest rate & Savings & Remittances \\
\hline NGO-MFI & 1993 & Country-wide & $\begin{array}{l}\text { Mid-low income and } \\
\text { poor clients }\end{array}$ & No & $3-18$ & no & No \\
\hline $\mathrm{ABC}$ & 1997 & Country-wide & $\begin{array}{l}\text { Mid-low income and } \\
\text { poor cliets }\end{array}$ & No & $2-3$ & No & No \\
\hline $\mathrm{RCCs}$ & 2000 & Country-wide & All farm households & $\begin{array}{l}\text { No. but yes for } \\
\text { large loans }\end{array}$ & $\begin{array}{l}0.9-2.3 \text { times basic } \\
\text { rate }\end{array}$ & Yes & Yes \\
\hline $\mathrm{UCB}$ & 2002 & Urban areas & Laid off workers & $\begin{array}{l}\text { Guarantee } \\
\text { companies }\end{array}$ & $\begin{array}{l}\text { Basic rate with } \\
\text { subsides } \\
\text { government }\end{array}$ & Yes & Yes \\
\hline $\mathrm{MCCs}$ & 2005 & 5 provinces & $\begin{array}{ll}\text { Farmers } & \text { and } \\
\text { microenterprises } & \end{array}$ & Yes & Around 20 & No & No \\
\hline VTBs & 2006 & 6 provinces & $\begin{array}{ll}\text { Farmers } & \text { and } \\
\text { microenterprises } & \end{array}$ & Yes & $\begin{array}{l}0.9-2.3 \text { times basic } \\
\text { rate }\end{array}$ & Yes & No \\
\hline RMCCs & 2006 & 6 provinces & $\begin{array}{l}\text { Member farmers and } \\
\text { micro enterprises }\end{array}$ & No & $\begin{array}{l}0.9-2.3 \text { times basic } \\
\text { rate }\end{array}$ & Yes & No \\
\hline $\begin{array}{l}\text { Lending } \\
\text { companies }\end{array}$ & 2006 & 6 provinces & $\begin{array}{ll}\text { Farmers } & \text { and } \\
\text { micro-enterprises } & \\
\end{array}$ & Yes & $\begin{array}{l}0.9-2.3 \text { times basic } \\
\text { rate }\end{array}$ & no & No \\
\hline $\begin{array}{l}\text { Poverty } \\
\text { alleviation } \\
\text { loans }\end{array}$ & 2006 & country-wide & $\begin{array}{l}\text { Mid-low income and } \\
\text { poor clients }\end{array}$ & No & Less than basic rate & Yes & Yes \\
\hline Postal savings & 2007 & Country wide & All farm households & Yes & $\begin{array}{l}0.9-2.3 \text { times basic } \\
\text { rate }\end{array}$ & Yes & Yes \\
\hline $\begin{array}{l}\text { Commercial } \\
\text { Bank }\end{array}$ & 2005 & $\begin{array}{l}\text { More than } 10 \\
\text { regions }\end{array}$ & $\begin{array}{l}\text { Micro-enterprise and } \\
\text { disadvantages people }\end{array}$ & No & Around 20 & yes & Yes \\
\hline \multicolumn{8}{|c|}{ Donor funded MFI projects and others } \\
\hline UNDP & 1995 & 17 provinces & Group lending & no & 8 & yes & - \\
\hline UNFPA & 1998 & 13 provinces & $\begin{array}{l}\text { Farm households and } \\
\text { groups, also training }\end{array}$ & no & 8.77 & no & - \\
\hline UNICEF & 1996 & 13 provinces & $\begin{array}{l}\text { Women clients } \\
\text { and training }\end{array}$ & no & 9.6 & yes & - \\
\hline Heifer Project & 1985 & 13 provinces & Farm households & no & 6 & no & \\
\hline World Vision & 1997 & 1 province & Farm households & no & 4 & & \\
\hline $\begin{array}{l}\text { Oxfam Hong } \\
\text { Kong }\end{array}$ & & Country-wide & Village & no & $\begin{array}{l}\text { Community } \\
\text { decided }\end{array}$ & yes & - \\
\hline CIDA & 1997 & 1 province & Farm households & no & $7-10$ & yes & - \\
\hline
\end{tabular}

Sources: CAM, 2008, Druschel,(2002), Tang (2009) 


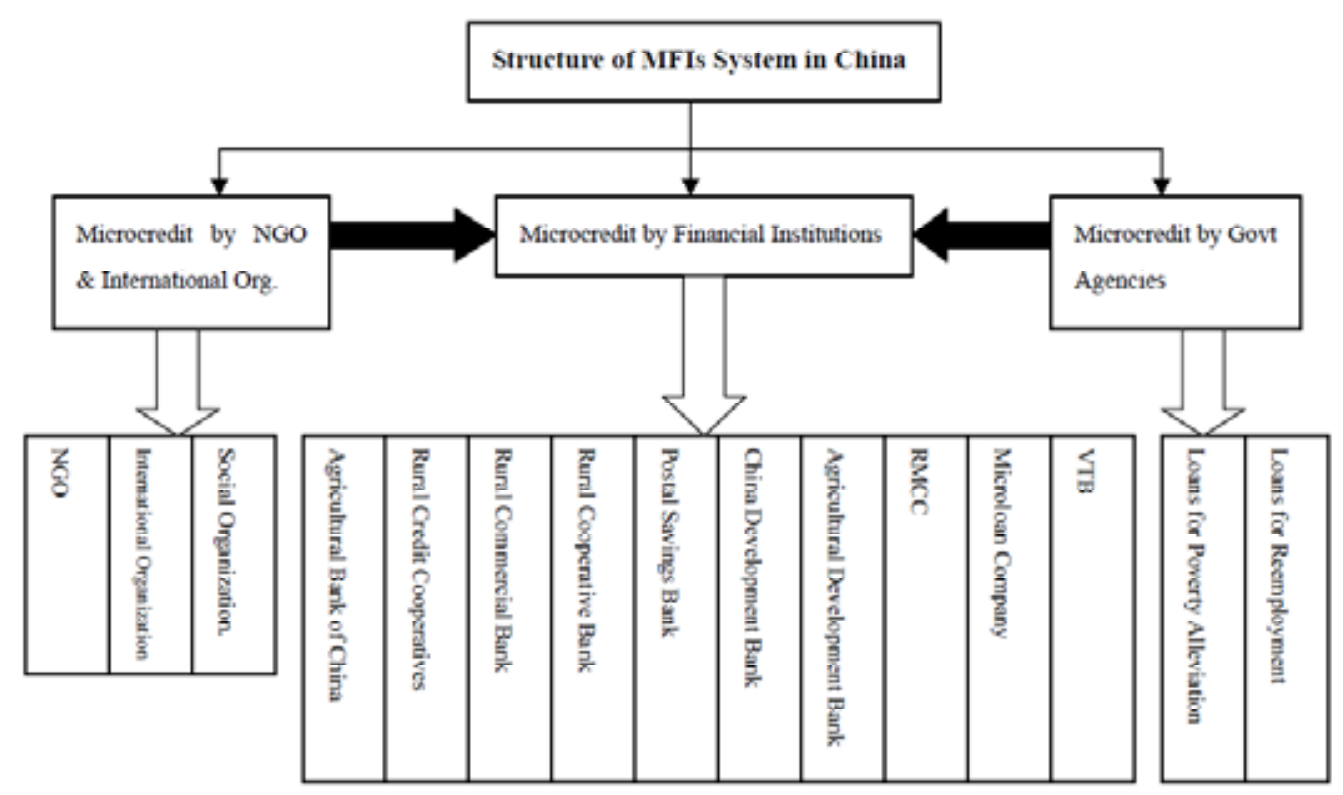

Source: He, Guangwen, (2009)

Figure 1. Structure of MFIs system in China 